\title{
T-TIP against the wall: feasibility, resistance, and consequences for third countries
}

\author{
T-TIP contra a parede: viabilidade, resistência \\ e consequências para países terceiros
}

DOI: $10.21530 /$ ci.v12n1.2017.590

Ana Paula Tostes ${ }^{1}$

\begin{abstract}
The objective of the article is to analyze the Transatlantic Trade and Investment Partnership (T-TIP) as a new model of international agreements, the reasons for resistance and the consequences for third countries that are dependent on trade with the United States and the European Union (EU). Special attention is given to the relationship between Brazil and the EU in the context of this new trend of trade partnerships. Using a theoretical approach based on neoliberal institutionalism (KEOHANE, 2005; KEOHANE, NYE, 1989, 2002), the article presents a historical overview of the transatlantic negotiations and a critical analysis of the innovative aspects it brings. Even considering the potential unfeasibility of the T-TIP, it must be understood as part of a new generation of trade and investments (BALDWIN, 2011, 2008). Similar to the Trans-Pacific Partnership, the North American Free Trade Agreement and the Comprehensive Economic and Trade Agreement, the T-TIP aims to introduce a robust regulatory framework that would affect multilateralism. These "big treaties" include commitments that are not covered by the World Trade Organization and mandates that are not traditionally attributed to international institutions. Therefore, they bring to light new elements in international trends that are yet to be fully understood.
\end{abstract}

Key-words: T-TIP, international relations, European Union, United States, Brazil.

\section{Resumo}

O objetivo do artigo é analisar o Tratado Transatlântico de Cooperação em Comércio e Investimento (T-TIP) como um novo modelo de acordos internacionais, revelando razões da resistência e consequências para os países terceiros que dependem do comércio com Estados Unidos e União Europeia (UE). O artigo foca a relação entre o Brasil e a UE no contexto

1 Pesquisadora Visitante na Universidade Livre de Berlim (ULB) e Professora Adjunta no Departamento de Relações Internacionais da Universidade do Estado do Rio de Janeiro (UERJ).

Artigo submetido em 25/11/2016 e aprovado em 28/03/2017. 
da nova tendência de parcerias comerciais. Utilizando uma abordagem teórica baseada no institucionalismo neoliberal (KEOHANE, 2005, KEOHANE, NYE, 1989, 2002), o artigo apresenta uma visão histórica das negociações transatlânticas e uma análise crítica dos aspectos inovadores que ela traz. Mesmo considerando a potencial inviabilidade do T-TIP, é relevante entender que se trata de um caso dentre outros que faz parte de uma nova geração de tratados de comércio e investimentos (BALDWIN, 2011, 2008). Semelhante ao Tratado de Parceria Transpacífico, ao Acordo de Livre Comércio da América do Norte e ao Acordo Econômico e Comercial Global, o T-TIP visa introduzir um marco regulatório robusto que pode impactar o multilateralismo. Esses "grandes tratados" incluem novos compromissos não incluídos na Organização Mundial do Comércio e competências que tradicionalmente não são atribuídas às instituições internacionais, logo trazem novidades pouco compreendidas sobre novas tendências de institucionalização internacional.

Palavras-chave: T-TIP, relações internacionais, União Europeia, Estados Unidos, Brasil.

\section{Introduction}

Since the adoption of the New Transatlantic Agenda (NTA) by Europe and the United States (US) in 1995, several initiatives on transatlantic cooperation between corporations and governments have been undertaken. Transatlantic Regulatory Cooperation (TRC) initiatives have made progress in reducing costs for businesses and consumers in a few sectors of the economy in both regions. When European and American leaders instructed the Transatlantic Economic Council to establish a new joint High-Level Working Group on Jobs and Growth (HLWG) in 2011, their goal was to identify and assess opportunities for strengthening transatlantic trade and investment relations, especially in areas with the highest potential in terms of job creation and growth. The main goal was to respond to the specific characteristics of transatlantic economic relations "by identifying policies and measures" to increase EU-US trade and investment flows to support "mutually beneficial job creation”, economic growth, and international competitiveness (HLWG Final Report, 2013). The main concern of the leaders heading the joint efforts was to minimize the impacts of the US crisis and the sovereign debt crisis in the Eurozone on inter-regional trade and the global economy.

The EU-US HLWG was founded to boost transatlantic trade and investment between the EU and the US, which were looking for a more "flexible" and "open-minded attitude" towards negotiations and the development of trade solutions. 
The HLWG's establishment, however, coincides with the emergence of new thinking in the wake of the failure of multilateral trade negotiations in the WTO Doha Round framework. The report of the Transatlantic Taskforce on Trade (TATF) emphasized the need for a new understanding of several aspects of the transatlantic relationship (COOPER, 2014). When we examine the Transatlantic Trade \& Investment Partnership Advisory Group Meeting Report (2014), it is not difficult to identify efforts to build closer relations between the two cultural, political, and economic world powers (Transatlantic Trade \& Investment Partnership Advisory Group Meeting Report. 2014). Since the 1990s, both US and European multinational companies have held divergent views on how to regulate markets for both goods and services, as these regulations are the principal barriers to transatlantic commerce. The main reason these companies seek to achieve greater harmonization in standards and regulatory procedures is to reduce costs imposed by having to comply with two different sets of regulations and standards. Regulatory cooperation is an umbrella concept that incorporates a broad range of activities. The acceptance of common principles and standards is seen as a key way to boost trade and investment between Europe and the US. This is exactly what was done within the EU to consolidate its common market (STUDY ON "EU-US HIGH LEVEL WORKING GROUP FINAL REPORT”. 2012).

Establishing rules at the regional level and monitoring compliance with them can foster a more favorable business climate by reducing uncertainties (KEOHANE, 2005). Institutional arrangements and commitments also help to reduce uncertainties and to save time. Furthermore, participation in regional institutions provides a more precise picture of what is important to partner countries, what the parties involved can expect from each other and how they can develop greater mutual trust (AXELROD, 1983). On one hand, compliance can be costly, as can the formulation of rules and new institutions beyond a certain point. On the other hand, however, in the case of heterogeneous populations and situations where preferences for policies and institutions differ from one group to the next, it is worth weighing the costs and benefits of certain integration policies (ALESINA, LA FERRARA, 2005).

Under Obama's administration the economic policy has addressed the establishment of high-standard rules for trade as a vital issue within the global economy. As one of the most ambitious efforts geared towards achieving convergence and aligning policies, the Transatlantic Trade and Investment Partnership (T-TIP) 
appeared as the biggest inter-regional initiative of its kind. Some even go so far as to call it the "agreement of the $21^{\text {st }}$ century" (BALDWIN, 2011, 2008). If we consider governance as formal and informal processes and institutions that guide and restrict collective action (KEOHANE, NYE JR, 2002), it is important for us to analyze the new trend in trade and investment agreements and how they affect global governance. Treaties such as the North America Free Trade Agreement (NAFTA), the Comprehensive Economic and Trade Agreement (CETA), the Trans-Pacific Partnership (TPP), and the Transatlantic Trade and Investment Partnership (T-TIP) are pioneering agreements due to the institutional innovations they bring and the commitments made by member states.

According to Baldwin (2011), there is a new generation of treaties that introduce strong regulations, expand negotiations to new sectors and will have strong impacts on third countries. The scope of these "big treaties" go beyond commercial relations between countries and can affect civil society and domestic policies. While there are many innovative commitments in the new generation of trade and investment treaties that deserve to be broadly explored, the scope of this article will be limited to the history of the T-TIP and the most important and controversial issues to be agreed upon by the member states. A critical overview of the potential impacts of the T-TIP on the institutional level can help understand the consequences of other treaties of a similar magnitude, such as the TPP, CETA, and NAFTA. It is worth highlighting that one of the most controversial issues is the inclusion of a mechanism to settle conflicts that may emerge over the rights and duties agreed upon in the treaty: "investor-state dispute settlement" (ISDS). ${ }^{2}$ ISDS systems generally have full jurisdiction over conflicts and do not allow for any interference from or reviews by the national courts of member states. The ISDS would help investors overcome difficulties they face when their country of origin does not find it politically expedient to bring their case before the International Court of Justice. However, it means that the investors would have full guaranties for their investments, whereas civil society has none regarding the commitments of the investors. Furthermore, the US and the EU are so important economically to third countries that direct cooperation between the two regions will necessary impact the economies of other states.

2 This is a type of international arbitration and an instrument of international public law used in other bilateral and multilateral investment treaties (NAFTA, for example) in which disputes and debts are settled without any interference from national legal institutions. 
Ruggie (1992) defined multilateralism as a system of general principles and rules in which there is no discrimination between states. Based on this definition, in a multilateral world, global institutional frameworks are expected to treat all states equally. One would not expect discriminatory mechanisms that establish special benefits for a small group of countries to be adopted. The analysis of the new wave of "big treaties" provides a critical view of the risks that the alignment of powerful states' trade and investment interests in a comprehensive agreement pose for multilateralism.

The objective of the article is to analyze the T-TIP as a new model of international partnership, while explaining criticisms and reasons for support and rejection of innovative rules and commitments included in the agreement. Even though Donald Trump's victory in the US may mean the death of the T-TIP, the article aims to present the origins of the transatlantic negotiation in the context of a critical interpretation of the innovative rules emerging in the new trend of multilateral and bilateral trade and investment treaties. For this study, a theoretical approach based on neoliberal institutionalism (KEOHANE, 2005; KEOHANE, NYE, 1989, 2002) was adopted. As the potential impacts of these treaties on third countries and multilateralism in general are quite significant, we will examine in more detail the relationship between the EU and Brazil and other BRICS countries. The article begins by presenting a historical overview of the interests and goals of the parties of the treaty in which the context and challenges of the US-EU relationship during negotiations are highlighted. Here, we introduce a few issues and sticking points of the T-TIP in order to better understand the innovative aspects of the new generation of trade treaties. In the second part of the article, we will discuss the uncertain future of the T-TIP and its implications for Brazil-EU relations.

\section{The US and EU partnership and the challenges on the road}

As has already been mentioned, the U.S.-EU relationship is the largest in the world. It makes up nearly half of global GDP. We trade about \$1 trillion in goods and services each year. We invest nearly $\$ 4$ trillion in each other's economies. And all that supports around 13 million jobs on both sides of the Atlantic. And this potentially ground breaking partnership would deepen those ties. It would increase exports; decrease barriers to trade and investment, as part of broader growth strategies in 
both our economies. It would support hundreds of thousands of jobs on both sides of the ocean. (...) I can tell you that it has been warmly received in the U.S. as well, both in our Congress and in our business community. (...) America and Europe have done extraordinary things together before and I believe we can forge on economic alliance as strong as our diplomatic and security alliances - which, of course, have been the most powerful in history. (...) This Transatlantic Trade and Investment partnership is going to be a priority of mine and my administration. (...) it has to be part of a comprehensive strategy that we pursue on both sides of the Atlantic. (THE OBAMA WHITE HOUSE, 2013) 3

The US and the EU are the two big centers of power of the West, although the economic crisis is still around. Together, the US and the EU already retain the largest bilateral trade and investment relationship in the world, roughly $31 \%$ of the world trade and over $49 \%$ of the world GDP, representing a trade of about \$1trillion in goods and services each year, an investment of nearly \$ 4 trillion in each other's economies, and all that supports around 13 million jobs on both sides of the Atlantic. In his statement of 2013, President Obama made clear the US position for strengthening the transatlantic partnership: First, Obama himself appeared engaged in this project. Second, he tried to send the message that the Presidency, the Congress and the business community are all interested in the T-TIP; in other words, it seemed that there was no domestic conflict about the whole intention to overcome potential sensitivities to achieve the T-TIP at that time. Third, the trade and investment alliance seemed as the continuity of the military and defense alliance that resulted in the NATO. Also, President Obama attested in his talk that diplomatic and security strategies were clearly proved as close and related by the historical cooperation between the two regions.

Indications of the US government's intentions appeared once again in one of Obama's last international moves to get the T-TIP approved. In his visit to Berlin in November 2016, Obama and German Chancellor Angela Merkel discussed transatlantic cooperation and Russia in the immediate aftermath of Donald Trump's election victory one month earlier. According to Obama and Merkel, "the future is already happening and there will not be a return to a world before globalization" and "Germans and Americans have to seize the opportunity to shape

3 This is part of the President Obama's statement on the Transatlantic Treaty for Trade and Investment partnership in Lough Erne, Northern Ireland in June $17^{\text {th }}$, 2013. The announcement was about the first round of the Treaty negotiations to have place in Washington on July $8^{\text {th }} 2013$. 
globalization according to their values and ideas" (MERKEL, OBAMA, 2016). The leaders launched a joint appeal in defense of the T-TIP in the Germany weekly WirtschaftWoche:

Negotiations started three years ago and, considering the complexity of these issues, have made solid progress. An agreement that knits our economies closer together, based on rules that reflect our shared values, would help us grow and remain globally competitive for decades to come. Today, many U.S. and European companies and employees already benefit from transatlantic trade and investments. Global markets and production chains are increasingly intertwined. We realize that decisions in one country have tangible effects in others. To meet all these challenges, we need rules that are currently being negotiated in the framework of T-TIP. (MERKEL, OBAMA, 2016)

This clearly illustrates how much energy President Obama put into this transatlantic cooperation initiative. He seemed convinced right until his final days in office that this project was of utmost importance to the US, especially considering the international crisis and China's growing power in a global scenario marked by uncertainty. China's position was confirmed by its investments in infrastructure in Russia: a few projects are still under negotiation, such as the Russia-China gas pipeline, a deep-water port in Crimea, and a railway system in Russia's Far East. By building closer relations with Russia, Kazakhstan, and Belarus, China is placing its bets on these relations serving it well in the future - a strategy supported by the current Chinese foreign ministry.

While other economic and political powers were seeking new joint ventures in the East, Merkel and Obama were big supporters of the negotiations to build a transatlantic free trade and investment corridor. Since 2013, the US and the EU have held ten rounds of negotiations; the first was in Washington, D.C. between July 8 and 12, 2013. The complexity of the negotiations, their scope and scale, and the number of sectors and policies covered under the ambitious trade agreement affect the progress of ongoing talks. That said, the goal of building closer investments and trade relations was not merely a result of the crisis. In fact, for most trade agreements, it has taken much longer than a couple of years to conclude negotiations. The scale of the T-TIP in particular is too large to be achieved in a short period of time. To add to this, both partners have faced new security issues recently. The long duration of such a negotiating process could 
be extended even further in light of changes in government, such as the election of Trump in the US. In the case of Angela Merkel, although she is favored to win Germany's upcoming elections, she still has to go through the democratic process of electing the new Chancellor in 2017.

While EU institutions have already approved the T-TIP, some EU member states were still uncomfortable with the bilateral agreement. On the other side of the ocean, the new US president committed to not signing the treaty during his campaign. In this context, however, we still consider the strength of the bilateral relations between the US and the EU as well as its consequences to the global trade beyond the Trump administration. It is important to understand the complexity of implementing the T-TIP from different points of view, especially as similar institutional innovations exist in NAFTA and CETA, which are still in effect - or, at least, as of now they are.

\section{What's new and why does it matter?}

Between 1980 and 1990, regionalist initiatives took on new characteristics and scope. The pursuit of market liberalization with the goal of reducing costs by strengthening cooperation between the member states of the agreements generated what is known as "open regionalism". In other words, contrary to "closed regionalism" of the past, a new phase of trade cooperation appeared in 1980s. The "open regionalism” entailed expanding not only partnerships among, but also the sectors involved in cooperation (FAWCETT, HURRELL, 1995). The context of the emergence of the "open regionalism" can be explained by the rise of neoliberalism, which promoted the reduction of state interference and greater market liberalization, with greater freedom to sign different kinds of agreements with various objectives as well as the emergence of a greater number of international institutions.

According to Fawcett and Hurrell (1995), in addition to the considerable variations in the level of institutionalization of the second wave of regionalism, its multidimensional nature makes it difficult to draw a clear line between the economy and politics. The proliferation of Preferential Trade Agreements (PTA) and international institutions in 1990s became crucial frame of emerging trust and predictability among the states and other international actors (KEOHANE, 1989). The significant growth of regional agreements has been interpreted as a 
"third wave of regionalism" in the context of the enhance of the interdependence among markets and states.

Baldwin (2011) identifies a complex relation known as the "trade-investment-service nexus", which arose from the new global value chains (GVCs). The complexity of the globalized world required new ways of cooperation and a search for greater institutionalization of standards and rights that affect gains in international trade. The scenario of the new GVC is the key for understanding the commitment of economic partners such as the EU and UE to broaden the scope of predictability in their trade relations. The globalization motivates the economic groups to operate internationally so they frame their activities through outsourcing and offshoring of their activities. International production, trade and investments are organized in different stages of the production. The whole process of production (from raw materials to finished products) and services are carried out wherever the necessary skills and materials are available at competitive costs and quality. The OECD has highlighted the broad range of policy implications of the GVCs.

Neoliberal institutionalism has dedicated to framing explanations about the emergence of the liberal order and the sophistication of international institutions in the post war world. The strategic interests of the Companies under the new GVCs can also be understood as rational choices. The production process is located in different countries, then regional agreements about broader issues can help to reduce costs and time in trading.

The implication of the new trade and investment treaties, however, is not only limited to the partners. In order to better understand the differences of the impact of existing commitments in the new trade and investments treaties as possible threat to multilateralism, Horn, Mavroidis, and Sapir (2009) developed a classification of the new anatomy of regional rules. According to the authors, to understand the new elements introduced by the mega-treaties, one must differentiate between the commitments they contain and the norms and rules of the WTO - that is, those that establish standards already recognized by the multilateral system of norms, called "WTO in" (or intra), and new kinds of commitments that end up prevailing in these cases. In the new trade and investments treaties, in addition to the WTO in-intra norms, one finds commitments that extend the deadlines or the scope on areas and issues beyond what has already been established by WTO norms. The new norms are referred to by the authors as "WTO plus". In these cases, deadlines can be extended or issues referring to obligations or rights already agreed upon 
at the WTO are included. Yet, the most notorious innovation is the expansion of commitments that are not contemplated or regulated by the WTO - classified as "WTO extra" (or "WTO-X"). The WTO extra-X norms include both new rules and new areas of negotiation; investment rules on new issues in the agreements; the definition of new procedures; as well as new principles and rights that involve relations at the country level. Thus, when we consider the international relations as an arena of collective actions, it is possible to understand the aim to enhance commitments by institutionalizing rule related to trade interests of powerful international actors. However, as much as new trade commitments are out of the WTO, the third countries have no access to participate on the establishment of the new trade rules. In other words, once new regulations are decided between strong markets such as the US and EU, the third countries depending on trading with the US and EU will have to follow all new rules and standards - even if they did not make part of the agreement.

\section{The sticking points and actors}

Although the content of the T-TIP and TPP negotiations has not been officially released to the public to protect national interests, the treaties' texts have been leaked several times. As the extent of the treaties and their political and legal impacts on the domestic level are now known, the societies of many countries involved have expressed dissatisfaction with the lack of transparency and the extensive nature of the agreements. There are concerns about how much these new models of regional integration have the potential to profoundly alter the development of global trade and affect multilateralism, as detailed above. In addition, their impacts will be felt not only internationally, but also domestically.

First, the new generation of trade and investment treaties could operate a real free trade zone, since the treaties aim to eliminate or substantially reduce barriers to the circulation of goods, services, and investments impacting societies and small business. Second, they cover new policy issues beyond trade, such as: intellectual property, labor laws, common environmental actions, etc. In this case, several typically domestic issues would escape from national institutions to be created. Finally, and maybe the most important, the new investment treaties create a legal framework for resolving disputes. It means that rather than creating certainty for foreign investors and states, the process of resolving investments 
disputes through arbitration has created uncertainty about the meaning of those tights and public international law. In other words, public international law rights have been articulated for the first time in investment treaties (FRANCK, 2005).

Even considering different points of view, it is still easy to understand why the T-TIP is less about trade than about increasing the power of corporations and making trade easier and cheaper (KHORAMA, 2015). The Treaty would lead to lower tariffs and therefore to lower income for states, though not to a very significant extent because tariffs are already quite low. Thus, removing remaining tariffs is expected to have very limited effects. "Therefore the focus of negotiating and modeling efforts is on non-tariff measures (NTM'S), or non-tariff barriers. These are procedures, laws and regulations other than tariffs or quotas that impede trade in goods and services between two countries." (RAZA et al., 2014, p. 41). In this context, since 2013 negotiating groups have set out respective approaches and ambitions in as much as twenty various areas that the T-TIP is set to cover. The negotiators met with 350 stakeholders to listen to formal presentations and answer questions about cutting differences in technical regulations, standards and certification.

Currently, the volume of trade between the EU and the US is already the largest in the world. Even so, transoceanic trade often costs companies' time and money: for example, when a car is approved in the EU, it has to undergo new safety tests in the US. The T-TIP was expected to reduce such costs and make products and services less expensive. It is too early to evaluate the impact of a transatlantic bilateral partnership on third countries and promises have been made to ensure fair access to the world market. Barker and Workman (2013) conducted a comprehensive survey of stakeholders to capture their views on the agreement. The survey ranked issues according to the importance attributed to them, the level of difficulty involved and the likeliness of them being approved, which helps us to understand more clearly the issues covered by agreements such as T-TIP. 


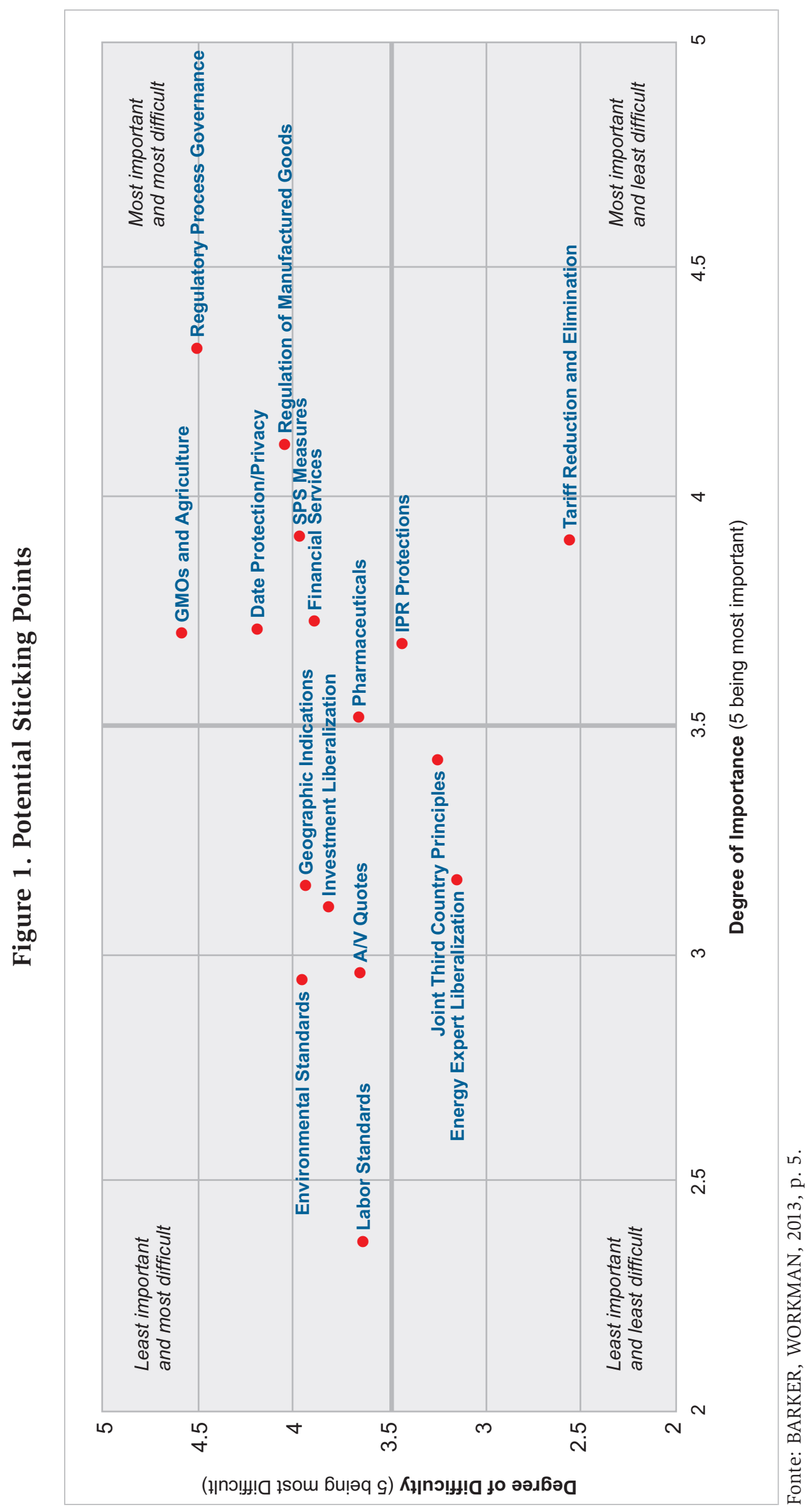


As we can see in figure 1 above, the findings are consistent with public statements by policymakers. The most difficult issues to negotiate are: market access for genetically modified organisms (GMOs) and agricultural products treated with hormones; convergence of regulations across multiple sectors; alignment of regulations on data protection and privacy; and harmonization of regulatory regimes and standards for manufactured goods. The most important issues are among the most difficult as well: GMOs and agriculture, and regulatory convergence. One surprising finding was that stakeholders do not see the convergence in pharmaceutical testing and approval requirements for new drugs and in environmental standards as something difficult to achieve or crucial (BARKER, WORKMAN, 2013, Charts 1 and 2, pp. 3-4).

Once the difficulties are overcome, the EU companies were estimated to be able to sell an additional $€ 187$ billion worth of goods and services a year to the US. This looks good news for jobs. A survey commissioned by Germany's Bertelsmann Foundation revealed however that the US incomes would rise $13.4 \%$ per capita thanks to the T-TIP, whereas those in Europe would only increase 5\%. Even under this disproportionateness of benefits, on balance, Europe has the most to lose if the T-TIP does not go through, since Europe has fewer options than America. Also, there would not be an easy task for the EU to overcome its asymmetries. Europe is experiencing a serious problem of competitiveness of the southern countries such as Greece, and there are differences in the financial rules and exchange rate policies to be reviewed. Also, the institutional procedures to approve a treaty like the T-TIP have to follow all the steps of negotiation, which takes time.

In this scenario, in light of the new US president's vow to stop the T-TIP negotiations, it is important to note two policy options that can effectively boost cooperation, according to the Trade Regulatory Cooperation Report (AHEARN, 2009): (1) attract high-level political support, and (2) increase dramatically the involvement of legislators (the US Congress and the European Parliament). The initiatives to reinforce these two policies have demonstrated their capacity to keep transatlantic cooperation alive.

Thus, the first policy can be associated with the initiative to create the Transatlantic Economic Council (TEC), in April 2007. The Council was designed, in part, to generate the kind of high-level political support that previous initiatives may have lacked. In other words, the institutionalization of the cooperation can bring better conditions to design the terms of the development of the partnership, 
making clear the steps needed to reach the agreement and the limits of the procedures that should be improved.

The second policy (2) is quite important considering the predominance of the executive as a driving force for cooperation. Thus, the involvement of the legislative branch could facilitate the harmonization of the regulatory issues. As well as domestic regulation of standards and measures are necessary in a growing market. Minimal regulation is necessary for the good heath of a free market. Thus, in an increasingly integrated transatlantic marketplace, Congress will be called upon to balance the often-competing demands of trade expansion and barrier reduction against domestic health and safety concerns (AHEARN, 2009).

Finally, supporters of the T-TIP and other new generation treaties such as NAFTA has agreed that these new models of partnership increase the volume of trade and investment with consequences for wages and jobs. Although, the benefits of the new generation treaties are not so evident with regard to real growth and employment. There are concerns in regulatory harmonization and the appropriateness of the ISDS regime in NAFTA (RODRICK, 2015) as well as studies that show benefits flowed to already-wealthy elites, not to workers, their families, and the general poorer population. In the case of NAFTA, "wages stagnated, social protections declined, and violations of worker's organization and collective bargaining rights continued unabated" (COMPA, 2014). Also, despite the good ex ante predictions, NAFTA led to the loss of a million US jobs, and a significant fall in wages (SCOTT CATO, 2015). "In Mexico, the increase in productivity reduced the foreseen increase in manufacturing jobs, and at the same time destroyed a million jobs in the agricultural sector." (BALLERA, 2015, p. 41). In general terms, the urgency of the T-TIP was justified by the need to act in geopolitical strategic way, the interpretation of the "West against the rest" presented as a "defensive" attitude. In reality however it was an "offensive" one, in other "to take advantage of economic, military and political domination so as to impose new regulations on a global scale regardless of multilateral institutions" (BALLERA, 2015, p. 39). As a consequence, companies and business groups from BRICS countries (Brazil, Russia, India, China and South Africa) have started to feel concerned about future preferences of the US and the EU approximation since the Obama administration started to speed the T-TIP. 


\section{If not the T-TIP there still is China and the others}

Neither the United States nor Europe has a monopoly on how to deal with a rising China. Indeed, that may be precisely the point. Both Brussels and Washington have enormous interests in getting the equation right, yet for one reason or another-political mistrust, commercial competition, cultural differences, or others-both have more frequently been at odds over policy toward China than they should be. (GILL, MURPHY, 2008, p. iv).

Gill and Murphy (2008) underlined how much Washington needs to vastly improve its understanding of China-Europe relations on the one hand and broaden transatlantic common ground regarding China's growing influence in the world on the other. China and Europe are important to US, so their steadily relationship has not been sufficiently observed by those against the T-TIP in the US According to the authors, the China-Europe relationship has improved in recent decades, has been institutionalized and has extended to several sectoral dialogues covering areas such as: agriculture, civil aviation, competition policy, customs cooperation, education and culture, information society, intellectual property rights, maritime transport, space cooperation, etc. (GILL, MURPHY, 2008, p. 10-11) Today, as China's influence in the world grows and as the European Union moves to recovery from the serious crisis of the euro, the US policy leaders strengthen its position forward constructing a transatlantic partnership under Obama administration. The T-TIP, then, has been seen as a reaction of the developed world to the accelerated growth of emerging countries, especially China.

Contrarily to what happened in the two past decades, the emerging markets became slow to make progress during the last years. According to the OECD's ${ }^{4}$ chief economist Pier Carlo Padoan, "the bottom line is that advanced economies are growing more and emerging economies are growing less." However, China is, as always, the exception among the BRICS countries (Brazil, Russia, India, China and South Africa).

While during the last Administrations of Presidents Lula and Dilma Rousseff the Brazilian foreign policy has been anchored in participating and playing a leadership role in multilateral forums, especially the BRICS, this emerging economy is involved in one of the most fragile regional integration processes. It has not been part of a bloc following a robust model of economic integration, nor is it participating in

4 The Organization for Economic Cooperation and Development (OECD) produces reports every 2 years on the economic and social development and democracy. 
any of the major transoceanic trade and investment treaties that are giving rise to a new dynamic of strategic cooperation and regionalism. The current scenario is that the US has demonstrated its strength again. There were positive results in unemployment, housing and business investments in US and Europe since 2012. However, we can conclude that the crisis has pushed the proximity of the two political and economic powers. The prospective of the T-TIP was to gains for the EU about 86 billion euros and for the US about 65 billion euro per year. The European business executives say that $80 \%$ of the benefits of an agreement would result from reducing the regulatory burden and bureaucracy, as well as from opening up services and public procurement markets. It is expected that every year an average European household would gain an extra $€ 545$ and the European economy would be boosted by around $0.5 \%$ of GDP, once the deal was fully implemented (TOSTES, 2015). Finally, we have seen a clearer attitude in making this partnership a more popular and visible initiative during the Obama administration, but the issue was avoided during the US presidency campaign. The Transpacific received critics and visibility but the T-TIP was spared by the candidates.

\section{BRICS and Brazil in the context of global powers}

The BRICS countries aimed to form a group of emergent economies that seek reforms in the liberal international order created after World War II. The result is the reordering of international coalitions, the search for new possibilities of pooling of interests and optimization efforts on development and economic growth in the existing liberal order that is sustained by the economic strength that the BRICS were able to show in international flows of trade and capital during the past two decades ago.

Most of countries that integrate the BRICS have large territories, large populations, a varying number of neighbors with whom they need to accommodate interests. Another important feature is that the BRICS countries are natural regional leaders, which can be involved in regional integrations. The discussion about the role of the countries, however, is based on the potential for economic growth and development, but these same countries face the problem of poverty and inequality, anchored in historical processes of social divisions as a legacy of dictatorships and past poverty. Recent past of violence and social conflicts are reflected in the significant difference between indices of human development and inequality when compared with the numbers of developed countries. This means 
that the BRICS countries have a dual ambition: beyond international insertion, they need to solve parallel problems involving domestic policy reforms, social policy adjustments, decreasing violence, poverty and inequality. The decision taken in the fourth BRICS Summit in New Delhi in 2012 and subsequently announced in the fifth BRICS Summit in Durban in 2013 to establish a development bank was achieved in the sixth Summit in Brazil in 2014, which was actually created to be a pivotal player among the BRICS countries. The New Development Bank (NDB) appeared as a promise to increase the weight of BRICS countries in global governance of development finance institutions.

According to the United Nations Development Programme (UNDP) data, China and Brazil have something in common; they made the best performance improvement of the Human Development Index (HDI) among the BRICS countries. According to the UNDP report of 2008, significant economic growth in China drew thousands of people out of poverty, but it remains a challenge to translate this growth equally in all aspects of social welfare and the entire Chinese population. The current China's 0.699 on the HDI represents a remarkable increase of $72 \%$ from the 0.407 it registered on this scale in 1980, or an average year-on-year growth of 1.7 percent. (ENGLISH PEOPLE, 2013)

On trade, despite a very lucrative period for both Brazil and China in the past two decades, the relationship is becoming increasingly asymmetrical. China still intends to reinforce the south-south characteristics of its relationship with Brazil, and the value of better agreements and the strength of the trade between the two countries are shared among them.

Although China became Brazil's main trading partner, Brazil does not figure among China's top ten trading partners (MINISTERIO DAS RELAÇÕES EXTERIORES, 2011). Moreover, relations between the two countries do not constitute a South-South exchange (a balanced exchange between developing countries), as official Brazilian rhetoric may suggest, but an increasingly NorthSouth relationship-with Brazil as an exporter of commodities and an importer of manufactured goods from China. Approximately 79 percent of Brazilian exports to China in the first quarter of 2010 were basic goods (soy, iron ore, and oil). And Brazil's imports from China were mostly electronic and capital goods. In 2000, 49 percent of Brazilian exports to China were basic goods.” (PEREIRA, NEVES, 2011)

Brazil has tried to address the asymmetries of the bilateral exchange with China, however domestic political battles and institutional imperfections are among major source of Brazil's lack of competitiveness. According to a Fitch ratings report 
from 2012: "China's Economic Rise Provides Mixed Benefits for Latin America”, the overall Latin America has benefited from the relationship with China by higher commodity prices, increased growth, increased investment, and improved governmental financials. However, as a result of Latin America's commodity specialization and China's transition into a higher value-added manufacturing exporter, according to the Fitch ratings in 2010, 92\% of Latin American exports to China were commodities. As a consequence, the trade deficit with China has doubled to $0.8 \%$ of regional GDP during 2006 - 2010, from $0.4 \%$ during 2001 2005. Therefore, several experts have argued that the long-term position for Latin American in this partnership would be poor and other sources for growth and trade such as services should be pursued.

\section{Brazil in the context of the feasibility of the T-TIP}

The BRICS countries are clearly grounded in regional political alliances and, at the same time, they actively seek to build stronger multilateral relations. However, unlike its most important trade partners, Brazil is lagging behind in the area of multilateral and bilateral trade agreements: it has no part in the "new generation treaties" on trade and investments. Furthermore, its agenda for preferential agreements is modest (only 22) and its collection of partners is smaller than what one would expect from a country that is seeking to establish itself as an emerging power on the global scene. At the same time, the US and the UE have chosen markedly different strategies for including provisions in their Preferential Trade Agreements (PTAs) that go beyond the World Trade Organization (WTO) agreements (HORN; MAVROIDIS; SAPIR, 2009).

The ambition to join the free trade zones with commitments dealing with issues going beyond the current WTO mandate (e.g. high level of standards regulation and property rights) is far from being the privilege of the wealthier nations though. On 2012, Colombia, Mexico, Chile and Peru signed the Pacific Alliance, which provides zero tariffs for $90 \%$ of goods traded between them. Chile and Peru, including also negotiating with the United States joining the Transpacific Trade Agreement, which includes nine countries on both sides of the ocean and promises to boost trade with Asia. Brazil, however, has tried hard to play a leadership role in the Mercosur since 1990s. ${ }^{5}$

5 Mercosur is composed nowadays by 5 members: Brazil, Argentine, Paraguay, Uruguay, and Venezuela. 
The picture is that Brazilian foreign politics is constrained by the Mercosur and Argentine, which is the buyer of most semi-manufactured Brazilian production but is now under domestic crisis that affect imports from Brazil. As Argentina is the third largest trading partner of Brazil, after China and the United States, every point within Argentinean growth or retraction of its economy means many millions of dollars less in foreign trade. The slowdown of the economy in Argentina made Brazilian exports to the country fall about $20.7 \%$ in 2012 , according to economic consultants of Buenos Aires. The sectors most affected were the auto parts, agricultural machinery and electronics, among others. The fall in imports from Brazil made Argentina's trade deficit with Brazil decrease in 2012 to \$ 1.5 billion - which means a reduction of $73 \%$.

Mercosur has become less of an economic and trade regional project, and more of political forum in recent years. Since the impeachment on Paraguay in 2012 and the entrance of Venezuela as a full member, Mercosur has been accused of becoming a political platform more than a framework for regional development. Anyway, the future of Mercosur can be directly associated to the development both at the multilateral level of the WTO and the interregional preferential level, among others, the T-TIP and TPP. Even considering that the impact of T-TIP on Latin American countries would vary, members of Mercosur, such as Brazil, can suffer with new standards and intellectual property rights. On the other hand, the success of the two big transoceanic Treaties would impact other multilateral mechanisms for regulating trade. The global multilateral trade system is to be impacted in a dimension we still cannot foresee.

Since Brazil was classified as a country of citizens with medium to high income levels, meaning that Brazil lost some of its current perks in trade relations with the European Union, the acceleration of Mercosur-EU negotiation become a matter of surviving. The Generalized System of Preferences (GSP) allowed the reduction of import tariffs on a number of items sold by developing nations the recent loss still needs to be calculated and new strategies need to be found urgently. In 2012 Brazil was the third biggest beneficiary, with sales of $\$ 2.3$ billion, behind India (US $\$ 4.5$ billion) and Thailand ( $\$ 3.7$ billion). In all, the US gives the advantage to 127 countries and territories under the GSP. Approximately 3,500 products used by the auto parts, construction, chemical, steel, capital goods and food again are taxed.

Besides, Brazilian exports of steel, machinery, fuel, beef and cotton go through the competition to sell to Europe, since the US sell the same products. For airplanes and cars, products manufactured here in Brazil have much competition in the 
US, European products, as in the EU, US products. Brazil's trade deficit raises urgency for new agreements. Indeed, there are two potential scenarios for Brazil: find new breathes with Mercosur or look for a way out the Mercosur. There is no way in between. At the same time that Chile and Peru are making agreements including free trade and bilateral agreements with the US, EU and China, Brazil shy it keeps waiting for Mercosur.

In the 1990s, the European market was the destination of about $30 \%$ of the Brazilian exports. Since then, there were fifteen years of conversation first launched in 1999. Both sides have missed deadlines and compromises. Nowadays, the EU is still a major market for Brazilian commodities, especially agricultural goods. However, the exports dropped to about $20 \%$. If the T-TIP gained breath, there is a risk that the US come to gain preference as an exporter of agricultural commodities for the European market, which directly affects Brazil.

\section{Conclusions}

The interdependent context associated to the complex relation known as the "trade-investment-service nexus" (BALDWIN, 2011), which arose from the new GVCs, reinforces the need for cooperation and the search for greater policy coordination between countries (KEOHANE, NYE JR, 1989). Thus, there is no disconnect between the way business operates beyond borders today and the US and the EU's methods of pursuing international trade. Comprehensive joint efforts to deregulate international trade is obviously a demand of big corporations and economic groups that operate around the world and do business with governments. The US and EU currently control about half of the supply of services in the world and account for one third of the global flow of goods. Although the two economic powers are still recovering from the crisis, defenders of the T-TIP argue that it can help boost cooperation between the regions, as it could result in companies saving millions of euros. If the two powers were to continue moving ahead with the transoceanic agreements, it would lead to a new global trade order with a balance of power that is completely different from the one described in predictions on the rise of the East. Although Obama and Merkel have said that the T-TIP could benefit their countries and regions, their affirmations seem to go against Ruggie's (1992) view on multilateralism. According to Ruggie, multilateralism is a demanding organizational form that requires its participants to renounce temporary advantages 
and the temptation to define their positions in terms of national interests. Also, multilateralism requires global actors to avoid ad hoc coalitions and adopting policies based on situational exigencies and narrow interests. "Yet [as] it is by no means a rare organization form in the world" (CAPORASO, 1992, p. 604), it is worth understanding the global consequences of comprehensive partnerships established between the leading economic powers of the international order.

It is crucial to highlight that transatlantic relations are already strong, even without the T-TIP. At the end of 2014, bilateral investments between Germany and the US totaled $\$ 339$ billion and created high-paying jobs in both countries. Since 2015, the US has become Germany's most important trading partner with a trade volume of 173 billion euros, and conversely, Germany has become a cornerstone of the US's economic relations with the EU. Indeed, the significance of transatlantic trade is even more impressive when we look at trade between the US and the EU as a whole: the trading volume in 2015 amounted to 620 billion euros, the largest between any two partners in the world.

Resistance to the treaty exists on both sides of the Atlantic. Yet, one cannot deny that the arguments of the European opponents are more sound. Critics claim that the treaty will benefit big traders and exporters of products produced on the large scale in particular. Furthermore, some issues are more sensitive for European activist groups than for the ones based in the US - namely, the environment and health, which involve different elements of concern and protections for the productive and trade sectors on both sides of the Atlantic. For T-TIP opponents in Europe, the regulatory measures expected to be adopted in the areas of food security, health, animal welfare, and the environment will bring more changes for European procedures and principles than it will for those in the US. Even before the recent leaks ${ }^{6}$ and the increase in protests and the rejection of the T-TIP emerged, shortly after negotiations were launched in July 2013, the Minister of State for Foreign Trade, the Promotion of Tourism and French Nationals Abroad, Matthias Fekl, warned the French Senate about the treaty's incompatibility with the fundamental principles of French policy. Examples are France's protection measures in the area of culture (especially the film industry) and agriculture, as well as its legal autonomy to resolve disputes in the future.

In 2016, after the EU Council of Ministers approved the T-TIP, Donald Trump was elected as the $45^{\text {th }}$ President of the United States. He committed to putting

6 In 2015, texts on the content of and positions on the T-TIP were leaked. The documents were obtained by Greenpeace and exposed by The Guardian. 
an end to the US's participation in the "big treaties" such as NAFTA, the TPP and the T-TIP. Trump may still surprise his electors, as he has made more promises than he can keep. In this context, this article hopes to have contributed to the analysis of possible or inevitable scenarios for a new form of governance being developed over the last ten years. Despite the current uncertainty about the future of trade treaties, it is fundamental to identify the pros and cons of such agreements, the impacts of their failure or success, and Brazil's role in decisions in which the country has acted mainly as a spectator.

\section{References}

AHEARN, Raymond J. Transatlantic Regulatory Cooperation: Background and Analysis CRS Report RL34735, August, 2009. Available at: < http://www.fas.org/sgp/crs/ row/RL34717.pdf > . Accessed at: 10 sep. 2016.

ALESINA, Alberto; LA FERRARA, Eliana. Ethnic Diversity and Economic Performance. Journal of Economic Literature. vol. 43, n. 3, 2005, pp.762- 800.

AXELROD, Robert. The Evolution of Cooperation. New York: Basic Books, 1983.

BALDWIN, Richard. 21 ${ }^{\text {st }}$ Century Regionalism: Filling the gap between $21^{\text {st }}$ century trade and $20^{\text {th }}$ century trade rules. World Trade Organization: Economic Research and Statistic Division, Staff Working Paper ERSD-2011-08, 2011. Available at: < https:// www.wto.org/englisH/res_e/reser_e/ersd201108_e.pdf > . Accessed at: 17 oct, 2016.

BALDWIN, Richard. The WTO tipping point, VoxEU.org, 1/7/2008 > . Available at: < http://www.voxeu.org/index.php?q = node/1345 > . Accessed at: 17 oct. 2016.

BALLERA, Ricard. The TTIP or Europe. In: KHORANA, Sangeeta (ed.) The Transatlantic Trade and Investment Partnership (TTIP) negotiations between the EU and the USA. Caught between myth and reality? Barcelona: CIDOB, 2015, chap 3 pp. 37-47.

BARKER, Tyson, WORKMAN, Garrett. The Atlantic Trade and Investment Partnership: Ambitious but Achievable. A stakeholder Survey and Three Scenarios. Washington DC, Atlantic Council/Bertelsmann Foundation. 2013.

COMPA, Lance. Labor Rights and Labor Standards in Transatlantic Trade and Investment Negotiations: An American Perspective. In: SCHERRER, Christoph (Ed.) The Transatlantic Trade and Investment Partnership (TTIP): Implications for labor. Munchen: Rainer Hampp Verlag, p. 120-136. Available at: < https://www.uni-kassel. de/einrichtungen/fileadmin/datas/einrichtungen/icdd/Publications/Volume5.pdf > . Accessed at: 10 sep. 2016.

COOPER, William. Trade Promotion Authority (TPA) and the Role of Congress in Trade Policy. CRS Report for Congress, vol. 13, January, 2014, Available at: < http://fas.org/ sgp/crs/misc/RL33743.pdf > . Accessed at: 1 aug. 2016. 
CAPORASO, James. International relations theory and multilateralism: the search for foundations. International Organization. vol. 46, n. 3 Summer 1992.

ENGLISH PEOPLE. China climbs on human development index. 16 mar. 2013. Disponível em: < http://english.peopledaily.com.cn/90883/8170028.html > . Acceded at: 10 mar. 2017.

FITCH RATINGS. China's Economic Rise Provides Mixed Benefits for Latin America. 2012. Disponível em: http://www.fitchratings.com/creditdesk/reports/report_frame. cfm?rpt_id $=677239>$. Acceded at: 10 mar. 2017.

FITCH RATINGS. Website. Disponível em: http://www.fitchratings.com/web/en/dynamic/ fitch-home.jsp > . Acceded at: 1 fev. 2017.

FAWCETT, Louise; HURRELL, Andrew (Orgs.). Regionalism in World Politics - Regional Organization and International Order. Oxford: Oxford University Press, 1995.

Fitch: China's Economic Rise Provides Mixed Benefits for Latin America, May, 9, 2012. Available at: < http://newamericamedia.org/2011/01/latin-america-divided-overties-with-china-growing-suspicions-over-chinese-presence-in-latin-america.php $>$. Accessed at: 10 sep. 2016.

FINAL REPORT HIGH LEVEL WORKING GROUP ON JOBS AND GROWTH

February, 2013. Available at: < http://trade.ec.europa.eu/doclib/docs/2013/february/ tradoc_150519.pdf > . Accessed at: 10 sep. 2016.

FRANCK, D. S.. The legitimacy crisis in investment treaty arbitration: privatizing public international law through inconsistent decisions. Fordham Law Review. 2005, pp. 1521-1625.

GILL, Bates; MURPHY, Melissa. China-Europe Relations. Implications and Policy Responses for the United States. Center for Strategic \& International Studies - CSIS. Washington DC, The CSIS Press, 2008.

ORGANISATION FOR ECONOMIC CO-OPERATION AND DEVELOPMENT (OECD). Global Value Chains. Disponível em: < http://www.oecd.org/sti/ind/global-value-chains.htm > . Acceded at: 1 fev. 2017.

HORN, Henrik; MAVROIDIS, Petros C.; SAPIR, André. Beyond the WTO? An Anatomy of EU and US preferential trade agreements. Brussels: Bruegel Blueprint Series vol. VII. 2009. Available at: < http://bruegel.org/wp-content/uploads/imported/publications/ bp_trade_jan09.pdf > . Accessed at: 21 nov. 2016.

KEOHANE, Robert. After Hegemony: Cooperation and Discord in the World Political Economy. 2. ed. Princeton: Princeton University Press, 2005.

KEOHANE, Robert O; NYE JR, Joseph. Power and interdependence: World Politics in Transition. New York: Harper Collins Publishers, 1989.

KEOHANE, Robert O.; NYE JR, Joseph. Power and Governance in a partially globalized world. London: Routledge, 2002.

KHORANA, Sangeeta (ed.) The Transatlantic Trade and Investment Partnership (TTIP) negotiations between the EU and the USA. Caught between myth and reality? Barcelona: CIDOB, 2015. 
MERKEL, Angela; OBAMA, Barack. The Future of Transatlantic Relations. WirtschaftsWoche. 2016. Available at: < http://www.wiwo.de/politik/ausland/us-wahlen/usa-and-germanythe-future-of-transatlantic-relations/14853710.html > . Accessed at: 21 nov. 2016.

MINISTÉRIO DAS RELAÇÕES EXTERIORES. Brasil e China no Reordenamento das Relações Internacionais: Desafios e Oportunidades. Brasília: Fundação Alexandre Gusmão, 2011. PEREIRA, C.; NEVES, J. Brazil and China: South-South Partnership or North-South Competition? Policy Paper. Foreign Policy at Brookings, n. 26, March, 2011. Available at: < https://www.brookings.edu/wp-content/uploads/2016/06/03_brazil_china_ pereira.pdf > . Accessed at: 1 dez. 2016 .

RAZA, Werner; GRUMILLER, Jan; TAYLOR, Lance; TRÖSTER; ARNIM, Rudi von. An Economic Assessment of the Claimed Benefits of the Transatlantic Trade and Investment Partnership (TTIP). In: SCHERRER, Christoph (Ed.) The Transatlantic Trade and Investment Partnership (TTIP): Implications for labor. Munchen: Rainer Hampp Verlag, 2014. pp. 41-99 Available at: < https://www.uni-kassel.de/einrichtungen/fileadmin/ datas/einrichtungen/icdd/Publications/Volume5.pdf > . Acceded at: 10 sep. 2016.

REUTERS. Website. Disponível em: http://www.reuters.com/article/2012/05/09/ idUS194499 + 09-May-2012 + BW20120509 > . Acceded at: 1 fev. 2017.

RODRIK, D. The War of Trade Models. Dani Rodrik's webblog. Unconventional thoughts on economic development and globalization. 4 May 2015 Available at: < http://rodrik. typepad.com/dani_rodriks_weblog/2015/05/the-war-of-trade-models.html. > Acceded at: 10 sep. 2016.

TOSTES, Ana Paula. The effect of the TTIP on the BRICS countries: the case of Brazil. In: ROY, Joaquín (Ed.) The New Atlantic Community: The European Union, The US and Latin America. Miami-Florida: European Union Center/Jean Monnet Chair, 2015.

RUGGIE, John Gerard. Multilateralism: The Anatomy of an Institution. International Organization. vol. 46, n. 3, july 1992.

SCOTT CATO, Molly. I've seen the secrets of TTIP, and it is built for corporations not citizens. The Guardian. 2 feb. 2015. Available at: < http:www.theguardian.com/commentis free/2015/feb/04/secrets-ttip-corporations-not-citizens-transatlantic-trade-deal > . Acceded at: 10 sep. 2016.

STUDY ON “EU-US HIGH LEVEL WORKING GROUP FINAL REPORT.” (Ministry of Economic Affairs, Agriculture and Innovation). Ecorys, Rotterdam, October 2012. Available at: < http://www.ecorys.nl/contents/uploads/factsheets/350_1.pdf > . Accessed at: 1 aug. 2016.

THE OBAMA WHITE HOUSE (official website), 2013 Available at: http://www.youtube. com/watch?v = A7w7OvujpkU > . Accessed at: 30 mar. 2016.

TRANSATLANTIC TRADE \& INVESTMENT PARTNERSHIP ADVISORY GROUP. Meeting Report. December 2014, Available at: < http://trade.ec.europa.eu/doclib/docs/2014/ december/tradoc_152937.pdf >. Accessed at: 10 sep. 2016.

UNDP Report 2008. Available at: < http://hdr.undp.org/sites/default/files/reports/268/ hdr_20072008_en_complete.pdf >. Acessed at: 1 dez. 2016. 